$\S=-1$

\title{
Stature Estimation Using Hand and Handprint Dimensions Among Malaysian Population
}

\author{
Nur Atirah G*, Khairulmazidah M \\ Faculty of Applied Sciences, Universiti Teknologi MARA, 40450 Shah Alam, Selangor, Malaysia \\ *Corresponding author E-mail:airatira89@gmail.com
}

\begin{abstract}
There are various studies of stature estimation which is very important for formulation of biological profile and is population specific. This study was conducted to estimate height using hand and handprint dimensions among Malaysian population. This study comprises 200 voluntary male and 200 voluntary female subjects with age ranging from 20 to 60 years. Eight anthropometric measurements were taken on each hand and its corresponding prints. All the data was statistically analyzed using IBM SPSS Statistic 19 software. The result indicated that hand length and handprint length has the strongest correlation with stature for male and female subjects. However, for unknown gender, it was showed that almost all of the hand dimensions measured in this study except for pinky finger length showed strong correlation with stature for both right and left hand while for handprint measurements, only hand length and palm length gave better correlation with stature. Formulae for stature estimation using various hand and handprint dimensions were derived successfully for both linear and multiple regression for the ease of data availability in future use.
\end{abstract}

Keywords: Forensic anthropology; Stature estimation; Hand anthropometry; Handprints; Regression analysis.

\section{Introduction}

Stature of an individual is part of biological profile and has an important role in the identification, which is needed in medicolegal practices. In forensic research, the knowledge of human biological variation is important as it helps to develop biological profiles for unknown victims or suspects which plays crucial component for crime investigation or mass disaster identification. In anthropometrics, the use of body part to estimate the physical characteristics of an individual is common for cases such as mass disaster, homicide, robbery, and airplane crash where only part of the body or print is found at the scene. For these reasons, it is difficult to determine stature using anatomical method, therefore mathematical methods based on linear and multiple regressions are used for reasonable solution. Apart from that, impression evidences such as fingerprint, footprint, shoeprint and tire mark can be classified as important evidences in forensic investigations. There are several research conducted using footprint for estimation of stature, which give positive significant correlation between footprint measurements, and stature [1], [2], [3], [4]. Another impression evidence that is also an important piece of evidence in forensic anthropometry is handprint, where one can obtain information such as height, weight and sex provided by formulae.

Several numbers of studies have presented the relation between stature and hand and handprint among different human population utilizing linear and multiple regression analysis [5], [6], [7], [8], [9]. The measurements of hand and handprint showed positive correlation with stature and they also found that hand length and handprint length has the strongest correlation and lowest SEE. Besides, the head, scapula and buttocks should also be touching the vertical board with the head is erect and eyes focused straight ahead. After that, the horizontal sliding bar is positioned on the linear regression equation. A research of stature estimation from hands and feet dimensions was done in North Indian population and it is indicated that there was a positive and statistically significant correlation between stature and all measurements [10]. This is supported by Uhrova et al. [11] where their result also proved that the hand and foot dimension can be used to estimate stature for Slovak population. Other than that, in Malaysian population, there are also a few studies of stature estimation using various part of body such as foot and lower limb dimensions [12], [13]. Therefore this study was conducted to estimate the stature by using hand and handprint dimensions among Malaysian population.

\section{Methodology}

The data for the present study were obtained from 400 Malaysian (200 males and 200 females) with age ranging between 20 and 60 years. This age range was chosen in accordance to the maturity age of male and female. None of the subjects selected had any history of hand or spine-related disease such as arthritis to prevent error of measurement. Research ethics committee of Universiti Teknologi MARA has approved this study (REC/82/15).

Each of the subjects' height (stature) was measured in standing position using stadiometer. The subjects were instructed to stand bare-footed on the flat uniform and touching the base of vertical board. The head must be positioned in the Frankfurt Horizontal (FH) plane where the subject is requested to maintain an erect position with their back in contact with the vertical board and their arm hanging by the side with palm facing the thighs. The heels were together, touching the vertical board of the stadiometer.

Contact point of the vertex of the head and stature was recorded. Standing height was measured to the nearest $0.1 \mathrm{~cm}$. 


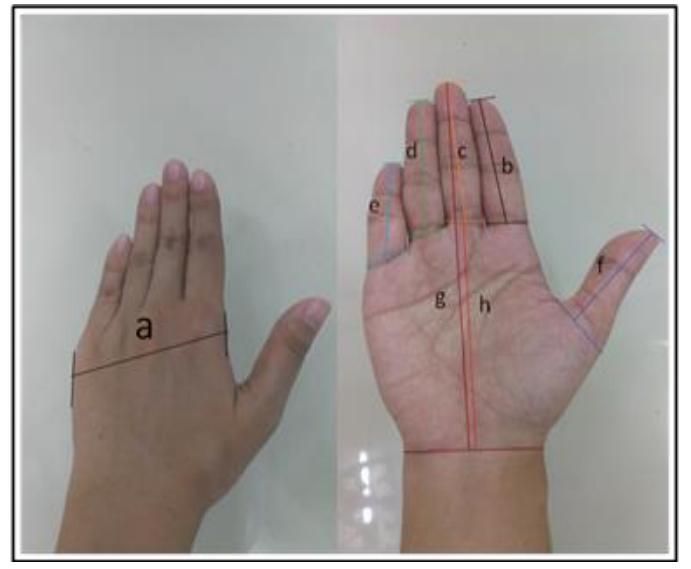

Fig. 1: Hand measurement: (a) hand breadth (HB); (b) index finger length (I); (c) middle finger length (M); (d) ring finger length (R); (e) pinkie finger length $(\mathrm{P})$; (f) thumb length $(\mathrm{T})$; (g) hand length $(\mathrm{HL})$; (h) palm length (PL).

Eight anthropometric measurements of both left and right hands were taken on each individual and their corresponding handprint using digital caliper. The eight measurements taken were hand length (HL), hand breadth (HB), palm length (PL), index finger length (I), middle finger length $(\mathrm{M})$, ring finger length $(\mathrm{R})$, pinkie finger length $(\mathrm{P})$ and thumb length $(\mathrm{T})$. The hand measurements were obtained by directly measuring the subject's hand. For handprint acquisition, the subjects were asked to smear a few drops of oil throughout the palm region of their hands. Subsequently, the subjects were asked to pat their hands onto A4 paper. The function of applying oil is to make the handprint more apparent. After that, magnetic powder was used to enhance that latent handprint deposited on the A4 paper. In order to preserve the handprint sample, laminated plastic were used to cover the developed handprint on A4 paper for further measurement.

Data obtained from the measurements were analyzed for its general descriptive statistics, correlation between the eight anthropometric measurements (Fig. 1) and the formulae for height estimations were derived for future use. All of these data were analyzed using Statistical Package for Social Sciences (SPSS). The regression analysis method was chosen in this study because the range of error is less than multiplication factor which confirmed that this method is more reliable for stature estimation [14].

\section{Results and Discussion}

\section{A. Descriptive statistics}

The mean stature for male was $167.587 \mathrm{~cm}$ (SD 5.832; range 153.4-181.8) and for female was $155.049 \mathrm{~cm}$ (SD 5.392; range 141.1-169.6). This showed that male stature is higher than female stature, similar findings found in literatures regarding stature estimation [6], [8], [15]. Table 1 shows the descriptive statistical analysis for the measurements of hand and handprint in both sexes. Mean value, standard deviation and correlation in eight anthropometric measurements on both bilateral sides are presented. In this study, the mean value of hand and handprint length is higher in left hand side than right hand for both male and female. This indicates that left hand is longer than right hand. However for hand breadth, the mean value of both gender showed that right hand is wider than left hand for both sexes. This is in accordance to Rastogi et al. [7], where right hand dimensions are larger than left hand dimensions in north and south Indian population.

Table 1: Descriptive statistics for hand and handprint measurements in males and females.

\begin{tabular}{|c|c|c|c|c|c|c|c|c|c|c|c|c|}
\hline Variables & Male & & & & & & Female & & & & & \\
\hline & Right & & & Left & & & Right & & & Left & & \\
\hline & $\begin{array}{l}\text { Mean } \\
(\mathrm{cm})\end{array}$ & $\begin{array}{l}\mathrm{SD} \\
(\mathrm{cm})\end{array}$ & $\mathrm{r}$ & $\begin{array}{l}\text { Mean } \\
(\mathrm{cm})\end{array}$ & $\begin{array}{l}\mathrm{SD} \\
(\mathrm{cm})\end{array}$ & $\mathrm{r}$ & $\begin{array}{l}\text { Mean } \\
(\mathrm{cm})\end{array}$ & $\begin{array}{l}\mathrm{SD} \\
(\mathrm{cm})\end{array}$ & $\mathrm{r}$ & $\begin{array}{l}\text { Mean } \\
(\mathrm{cm})\end{array}$ & $\begin{array}{l}\mathrm{SD} \\
(\mathrm{cm})\end{array}$ & $\mathrm{r}$ \\
\hline \multicolumn{13}{|l|}{ Hand } \\
\hline HL & 18.503 & 0.765 & $0.608 *$ & 18.589 & 0.780 & $0.614^{*}$ & 17.000 & 0.839 & $0.702^{*}$ & 17.036 & 0.828 & $0.719^{*}$ \\
\hline $\mathrm{HB}$ & 8.432 & 0.447 & $0.297 *$ & 8.317 & 0.463 & $0.265^{*}$ & 7.310 & 0.409 & $0.350 *$ & 7.210 & 0.406 & $0.338^{*}$ \\
\hline PL & 10.648 & 0.448 & $0.522 *$ & 10.703 & 0.480 & $0.509^{*}$ & 9.701 & 0.507 & $0.655^{*}$ & 9.743 & 0.489 & $0.668^{*}$ \\
\hline $\mathrm{M}$ & 7.852 & 0.417 & $0.553 *$ & 7.885 & 0.415 & $0.561^{*}$ & 7.300 & 0.427 & $0.607 *$ & 7.291 & 0.431 & $0.629 *$ \\
\hline $\mathrm{R}$ & 7.289 & 0.406 & $0.517 *$ & 7.348 & 0.414 & $0.551^{*}$ & 6.725 & 0.425 & $0.591^{*}$ & 6.733 & 0.426 & $0.603^{*}$ \\
\hline $\mathrm{P}$ & 5.879 & 0.390 & $0.382 *$ & 5.932 & 0.391 & $0.472^{*}$ & 5.401 & 0.399 & $0.529 *$ & 5.404 & 0.419 & $0.541^{*}$ \\
\hline $\mathrm{T}$ & 7.094 & 0.433 & $0.338^{*}$ & 6.932 & 0.425 & $0.412^{*}$ & 6.158 & 0.382 & $0.452 *$ & 6.159 & 0.385 & $0.412^{*}$ \\
\hline \multicolumn{13}{|l|}{ Handprint } \\
\hline HPL & 17.432 & 0.764 & $0.625 *$ & 17.510 & 0.764 & $0.615^{*}$ & 15.999 & 0.816 & $0.709^{*}$ & 16.084 & 0.792 & $0.693^{*}$ \\
\hline HPB & 7.734 & 0.467 & $0.201 *$ & 7.676 & 0.450 & $0.213^{*}$ & 7.120 & 0.401 & $0.267 *$ & 7.104 & 0.415 & $0.283^{*}$ \\
\hline PPL & 9.290 & 0.501 & $0.476^{*}$ & 9.364 & 0.504 & $0.476^{*}$ & 8.540 & 0.544 & $0.562 *$ & 8.646 & 0.524 & $0.562 *$ \\
\hline MP & 6.908 & 0.553 & $0.280^{*}$ & 6.927 & 0.538 & $0.296^{*}$ & 6.393 & 0.515 & $0.380^{*}$ & 6.384 & 0.546 & $0.396^{*}$ \\
\hline $\mathrm{RP}$ & 6.650 & 0.495 & $0.300 *$ & 6.679 & 0.512 & $0.368^{*}$ & 6.117 & 0.481 & $0.488^{*}$ & 6.126 & 0.457 & $0.394^{*}$ \\
\hline PP & 5.407 & 0.484 & $0.260 *$ & 5.458 & 0.491 & $0.272^{*}$ & 5.035 & 0.461 & $0.340 *$ & 5.052 & 0.432 & $0.401 *$ \\
\hline $\mathrm{TP}$ & 6.007 & 0.380 & $0.471 *$ & 5.900 & 0.424 & $0.494^{*}$ & 5.505 & 0.402 & $0.437 *$ & 5.423 & 0.401 & $0.364 *$ \\
\hline
\end{tabular}

*Correlation is significant at 0.01 level.

$\mathrm{SD}$ - standard deviation, $\mathrm{r}$ - Pearson correlation.

B. Correlation analysis

In this study, the subjects were divided into three groups, which are male and female groups while the third group is without gender discrimination and is identified as unknown group. Scatter plot graph was done to see the relationship between two parameters and to compare, which group would gives better prediction in the regression formulation analysis. Fig. 2-4 shows the relationship between stature and hand and stature and handprint length for both right and left sides for male, female and unknown group, respectively. As indicated in Table 1, the highest correlation to stature is hand length for both hand and also for handprint. The populations under study also exhibited that hand and handprint length has the highest correlation to stature in both males and females, similar to previous results in other countries [6], [8], [9]. This proves that the relationship between the two variables of interest does exist and they are in positive correlation. Furthermore, from the scatter plot graph, the unknown group shows better correlation compared to male and female group separately. Besides, the correlation coefficient (r) between stature and hand measurements in female group is higher than that in male group, which indicated that most probably, the predictive accuracy of stature estimation was higher in female than the male. This finding is supported by Sen et al. [16] in their study of stature estimation from lengths of index and ring fingers in a North-eastern Indian population. 


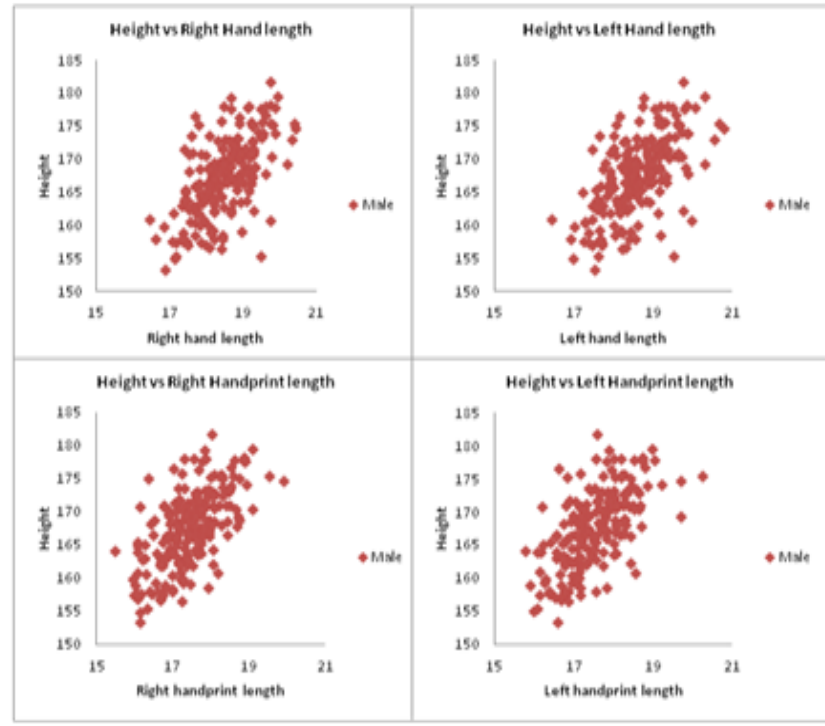

Fig.2: Scatterplot graphs for male group a) relationship between height and right hand length, b) relationship between height and left hand length c) relationship between height and right handprint length d) relationship between height and left handprint length.

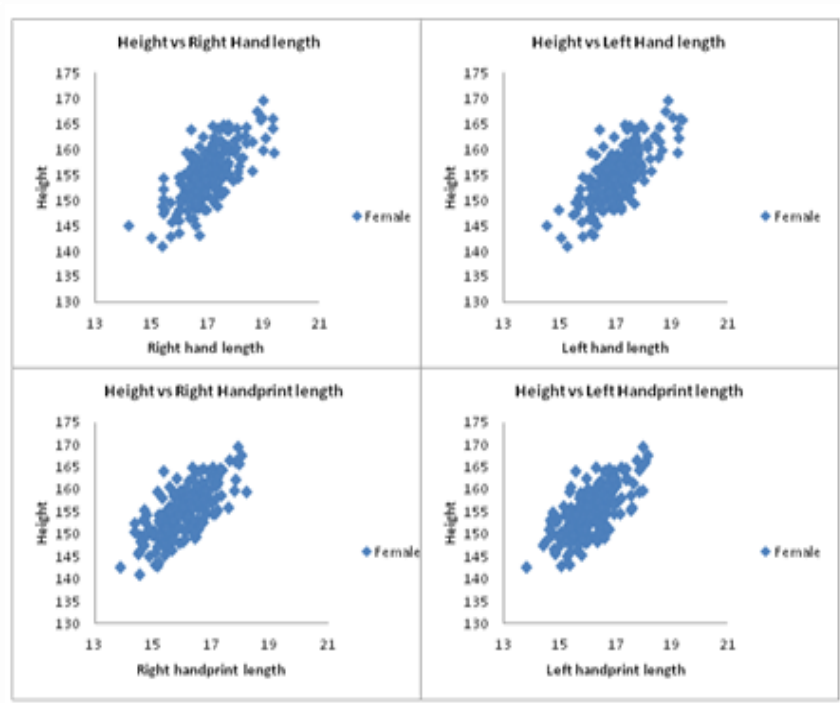

Fig.3: Scatterplot graphs for female group a) relationship between height and right hand length, b) relationship between height and left hand length, c) relationship between height and right handprint length d) relationship between height and left handprint length.

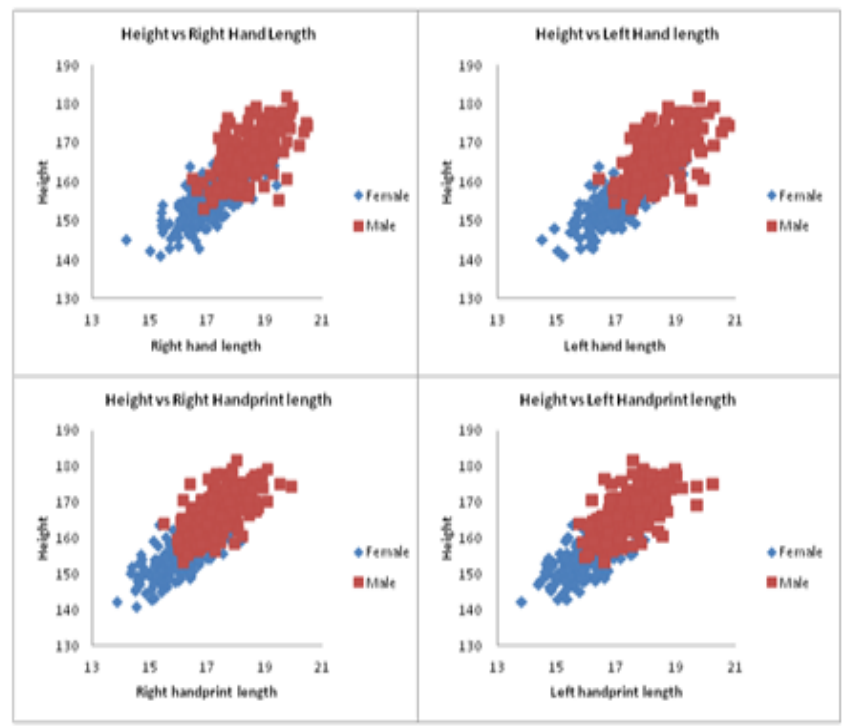

Fig.1: Scatterplot graphs for unknown group a) relationship between height and right hand length, b) relationship between height and left hand length, c) relationship between height and right handprint length d) relationship between height and left handprint length.

\section{Regression analysis}

Since all of the correlations of stature with eight variables measured in this study are statistically significant, the formulae for stature estimation using eight anthropometric measurements for hand and handprint were derived. Table 2-4 presented the equations from linear regression analysis for hand and handprint in male, female and unknown group. From the tables, it is shown that the lowest standard error of estimate (SEE) for hand and handprint dimensions is in the left hand side variables for all three groups. Besides linear regression, multiple regression analysis was also done to evaluate whether stature prediction accuracy can be improved by utilizing multiple variables. Therefore, a series of bilateral multiple regression equations were formulated where these are presented in Table 5-7. The three most accurate models with the lowest SEE are presented for both hands and handprints in all these groups. From the equations of regression analysis, the result shows that multiple regression have lowest SEE for male (hand; \pm 4.554 , handprint $; \pm 4.496$ ) and unknown group (hand; \pm 4.530 , handprint; \pm 4.673 ). Nonetheless, in female group, linear regression have the lowest SEE $( \pm 3.757)$ compared to SEE $( \pm 3.761)$ from multiple regression of hand measurements whereas in handprint measurements, the value of SEE $( \pm 3.786)$ is lowest in multiple regression analysis. For simple linear regression model, the measurement of hand length has the lowest standard error of estimate (SEE) for female group $( \pm 3.757)$, male group $( \pm 4.623)$ and unknown group ( \pm 4.614$)$. As expected, other research also has demonstrated that hand length is the most accurate measurement for estimating stature despite their different value of SEE since the total subjects for each study are not the same. For handprint analysis, the accuracy of multiple regression model is higher than linear regression models where the standard error of estimate value is the lowest in multiple variables compared to single variable and this finding is supported by Kanchan et al. [2] and Ishak et al. [6] in their study of static footprints and handprints measurement. 
Table 2: Linear regression equations for hand and handprint measurements (in $\mathrm{cm}$ ) in males.

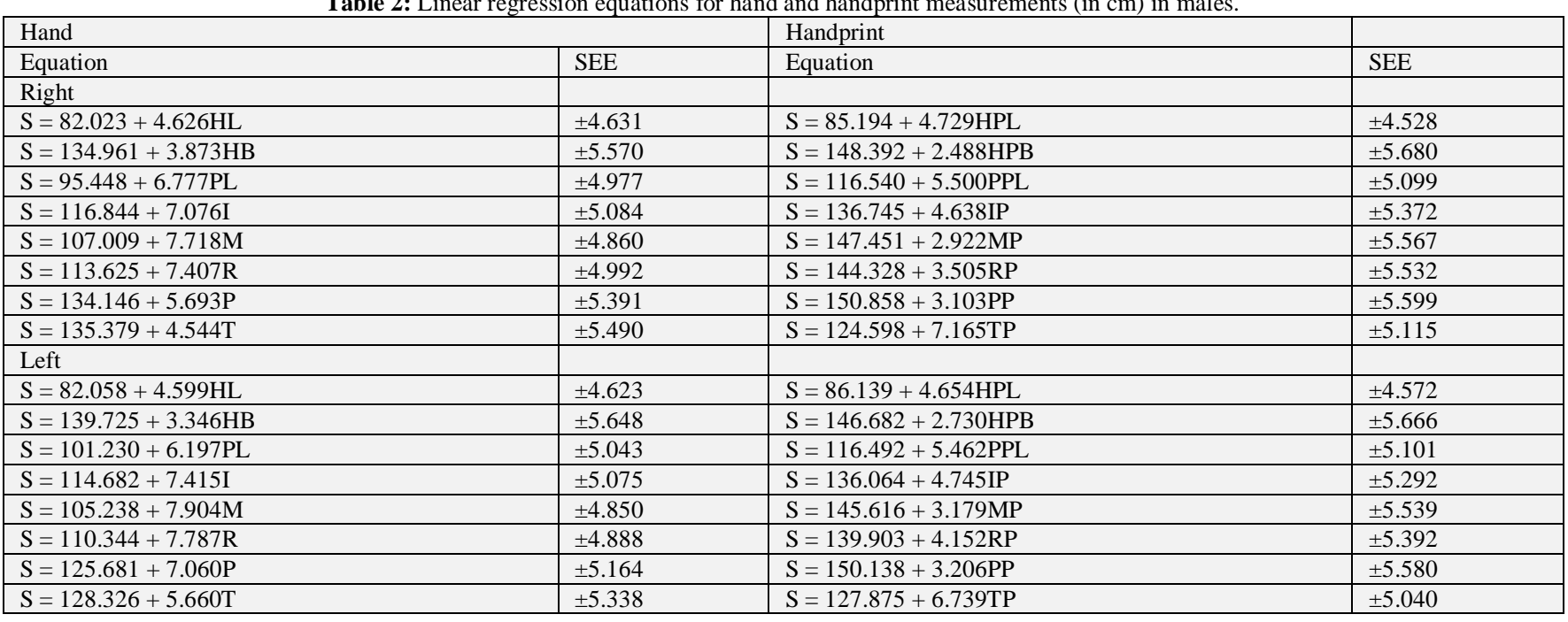

Table 3: Linear regression equations for hand and handprint measurements (in $\mathrm{cm}$ ) in females.

\begin{tabular}{|c|c|c|c|}
\hline \multicolumn{2}{|l|}{ Hand } & \multicolumn{2}{|l|}{ Handprint } \\
\hline Equation & SEE & Equation & SEE \\
\hline \multicolumn{4}{|l|}{ Right } \\
\hline $\mathrm{S}=78.325+4.513 \mathrm{HL}$ & \pm 3.848 & $\mathrm{~S}=80.081+4.685 \mathrm{HPL}$ & \pm 3.811 \\
\hline $\mathrm{S}=121.274+4.620 \mathrm{HB}$ & \pm 5.064 & $\mathrm{~S}=129.540+3.582 \mathrm{HPB}$ & \pm 5.210 \\
\hline $\mathrm{S}=87.414+6.972 \mathrm{PL}$ & \pm 4.084 & $\mathrm{~S}=107.456+5.572 \mathrm{PPL}$ & \pm 4.471 \\
\hline$S=103.465+7.778 \mathrm{I}$ & \pm 4.430 & $\mathrm{~S}=114.553+6.515 \mathrm{IP}$ & \pm 4.645 \\
\hline $\mathrm{S}=99.166+7.655 \mathrm{M}$ & \pm 4.297 & $\mathrm{~S}=129.585+3.982 \mathrm{MP}$ & \pm 5.000 \\
\hline $\mathrm{S}=104.645+7.495 \mathrm{R}$ & \pm 4.360 & $\mathrm{~S}=121.520+5.480 \mathrm{RP}$ & \pm 4.717 \\
\hline $\mathrm{S}=116.469+7.143 \mathrm{P}$ & \pm 4.589 & $\mathrm{~S}=134.997+3.981 \mathrm{PP}$ & \pm 5.083 \\
\hline $\mathrm{S}=115.762+6.379 \mathrm{~T}$ & \pm 4.823 & $\mathrm{~S}=122.379+5.867 \mathrm{TP}$ & \pm 4.862 \\
\hline \multicolumn{4}{|l|}{ Left } \\
\hline $\mathrm{S}=75.288+4.682 \mathrm{HL}$ & \pm 3.757 & $\mathrm{~S}=80.554+4.636 \mathrm{HPL}$ & \pm 3.833 \\
\hline $\mathrm{S}=122.715+4.484 \mathrm{HB}$ & \pm 5.089 & $\mathrm{~S}=129.394+3.621 \mathrm{HPB}$ & \pm 5.096 \\
\hline $\mathrm{S}=83.216+7.373 \mathrm{PL}$ & \pm 4.023 & $\mathrm{~S}=105.939+5.688 \mathrm{PPL}$ & \pm 4.396 \\
\hline $\mathrm{S}=101.154+8.167 \mathrm{I}$ & \pm 4.415 & $\mathrm{~S}=115.427+6.394 \mathrm{IP}$ & \pm 4.582 \\
\hline $\mathrm{S}=97.629+7.876 \mathrm{M}$ & \pm 4.203 & $\mathrm{~S}=130.592+3.84 \mathrm{MP}$ & \pm 4.881 \\
\hline $\mathrm{S}=117.466+6.955 \mathrm{P}$ & \pm 4.548 & $\mathrm{~S}=130.233+4.925 \mathrm{PP}$ & \pm 4.867 \\
\hline $\mathrm{S}=119.547+5.764 \mathrm{~T}$ & \pm 4.927 & $\mathrm{~S}=129.030+4.810 \mathrm{TP}$ & \pm 4.950 \\
\hline
\end{tabular}

Table 4: Linear regression equations for hand and handprint measurements (in $\mathrm{cm}$ ) in unknown gender.

\begin{tabular}{|c|c|c|c|}
\hline \multicolumn{2}{|l|}{ Hand } & \multicolumn{2}{|l|}{ Handprint } \\
\hline Equation & SEE & Equation & SEE \\
\hline \multicolumn{4}{|l|}{ Right } \\
\hline $\mathrm{S}=48.480+6.337 \mathrm{HL}$ & \pm 4.732 & $\mathrm{~S}=51.818+6.552 \mathrm{HPL}$ & \pm 4.705 \\
\hline $\mathrm{S}=93.419+8.627 \mathrm{HB}$ & \pm 5.822 & $\mathrm{~S}=95.984+8.799 \mathrm{HPB}$ & \pm 7.006 \\
\hline $\mathrm{S}=61.880+9.780 \mathrm{PL}$ & \pm 5.132 & $\mathrm{~S}=77.763+9.374 \mathrm{PPL}$ & \pm 5.889 \\
\hline $\mathrm{S}=76.123+12.337 \mathrm{I}$ & \pm 5.924 & $\mathrm{~S}=96.756+10.033 \mathrm{IP}$ & \pm 6.781 \\
\hline $\mathrm{S}=69.146+12.164 \mathrm{M}$ & \pm 5.758 & $\mathrm{~S}=112.156+7.395 \mathrm{MP}$ & \pm 7.202 \\
\hline $\mathrm{S}=95.359+11.690 \mathrm{P}$ & \pm 6.450 & $\mathrm{~S}=121.629+7.606 \mathrm{PP}$ & \pm 7.495 \\
\hline $\mathrm{S}=95.576+9.919 \mathrm{~T}$ & \pm 5.726 & $\mathrm{~S}=92.673+11.929 \mathrm{TP}$ & \pm 6.353 \\
\hline \multicolumn{4}{|l|}{ Left } \\
\hline $\mathrm{S}=49.232+6.292 \mathrm{HL}$ & \pm 4.614 & $\mathrm{~S}=51.574+6.537 \mathrm{HPL}$ & \pm 4.738 \\
\hline $\mathrm{S}=95.654+8.456 \mathrm{HB}$ & \pm 5.945 & $\mathrm{~S}=95.934+8.856 \mathrm{HPB}$ & \pm 7.002 \\
\hline $\mathrm{S}=60.183+9.892 \mathrm{PL}$ & \pm 5.030 & $\mathrm{~S}=75.975+9.484 \mathrm{PPL}$ & \pm 5.897 \\
\hline $\mathrm{S}=73.610+12.839 \mathrm{I}$ & \pm 5.874 & $\mathrm{~S}=98.698+9.747 \mathrm{IP}$ & \pm 6.724 \\
\hline $\mathrm{S}=68.296+12.257 \mathrm{M}$ & \pm 5.547 & $\mathrm{~S}=111.770+7.453 \mathrm{MP}$ & \pm 7.052 \\
\hline $\mathrm{S}=93.325+11.993 \mathrm{P}$ & \pm 6.102 & $\mathrm{~S}=117.698+8.311 \mathrm{PP}$ & \pm 7.248 \\
\hline $\mathrm{S}=91.238+10.704 \mathrm{~T}$ & \pm 5.905 & $\mathrm{~S}=99.308+10.693 \mathrm{TP}$ & \pm 6.544 \\
\hline
\end{tabular}


Table 5: Multiple regression equations for hand and handprint measurements (in $\mathrm{cm}$ ) in males.

\begin{tabular}{|c|c|c|c|c|c|}
\hline \multicolumn{3}{|l|}{ Hand } & \multicolumn{3}{|l|}{ Handprint } \\
\hline Equation & SEE & $\mathrm{r}$ & Equation & SEE & $\mathrm{r}$ \\
\hline \multicolumn{6}{|l|}{ Right } \\
\hline $\mathrm{S}=83.384+4.786 \mathrm{HL}-0.513 \mathrm{HB}$ & \pm 4.638 & 0.609 & $\mathrm{~S}=87.538+5.267 \mathrm{HPL}-1.007 \mathrm{HPB}-1.338 \mathrm{PPL}+1.275 \mathrm{IP}$ & \pm 4.518 & 0.634 \\
\hline $\begin{array}{l}\mathrm{S}=84.513+5.041 \mathrm{HL}-0.550 \mathrm{HB}-0.839 \mathrm{PL}+ \\
0.474 \mathrm{I}\end{array}$ & \pm 4.655 & 0.611 & $\begin{array}{l}\mathrm{S}=85.704+4.542 \mathrm{HPL}-0.923 \mathrm{HPB}-0.794 \mathrm{PPL}+1.240 \mathrm{IP}- \\
0.745 \mathrm{MP}+0.639 \mathrm{RP}-0.390 \mathrm{PP}+2.002 \mathrm{TP}\end{array}$ & \pm 4.516 & 0.644 \\
\hline \multicolumn{6}{|l|}{ Left } \\
\hline $\begin{array}{l}\mathrm{S}=84.721+24.055 \mathrm{HL}-1.068 \mathrm{HB}-20.057 \mathrm{PL}- \\
0.543 \mathrm{I}-20.494 \mathrm{M}+3.361 \mathrm{R}\end{array}$ & \pm 4.556 & 0.641 & $\mathrm{~S}=90.783+4.579 \mathrm{HPL}-1.627 \mathrm{HPB}-0.180 \mathrm{PPL}+1.630 \mathrm{IP}$ & \pm 4.543 & 0.629 \\
\hline $\begin{array}{l}\mathrm{S}=84.715+24.058 \mathrm{HL}-1.068 \mathrm{HB}-20.059 \mathrm{PL}- \\
0.539 \mathrm{I}-20.499 \mathrm{M}+3.370 \mathrm{R}-0.016 \mathrm{P}\end{array}$ & \pm 4.568 & 0.641 & $\begin{array}{l}\mathrm{S}=89.596+4.587 \mathrm{HPL}-1.645 \mathrm{HPB}-0.447 \mathrm{PPL}+1.054 \mathrm{IP}- \\
0.130 \mathrm{MP}+1.261 \mathrm{RP}\end{array}$ & \pm 4.542 & 0.634 \\
\hline $\mathrm{S}=82.219+25.053 \mathrm{HL}-21.053 \mathrm{PL}+3.148 \mathrm{R}$ & \pm 4.554 & 0.636 & $\begin{array}{l}\mathrm{S}=89.174+3.869 \mathrm{HPL}-1.462 \mathrm{HPB}-0.221 \mathrm{PPL}+0.858 \mathrm{IP}+ \\
0.106 \mathrm{MP}+1.309 \mathrm{RP}-0.841 \mathrm{PP}+2.272 \mathrm{TP}\end{array}$ & \pm 4.496 & 0.648 \\
\hline
\end{tabular}

Table 6: Multiple regression equations for hand and handprint measurements (in $\mathrm{cm}$ ) in females.

\begin{tabular}{|c|c|c|c|c|c|}
\hline \multicolumn{3}{|l|}{ Hand } & \multicolumn{3}{|l|}{ Handprint } \\
\hline Equation & SEE & $\mathrm{r}$ & Equation & SEE & $\mathrm{r}$ \\
\hline \multicolumn{6}{|l|}{ Right } \\
\hline $\mathrm{S}=79.337+4.600 \mathrm{HL}-0.341 \mathrm{HB}$ & \pm 3.856 & 0.703 & $\mathrm{~S}=82.962+4.781 \mathrm{HL}-1.230 \mathrm{HB}-0.503 \mathrm{PL}+1.392 \mathrm{I}$ & \pm 3.789 & 0.718 \\
\hline $\begin{array}{l}\mathrm{S}=79.132+4.312 \mathrm{HL}-0.363 \mathrm{HB}+ \\
0.859 \mathrm{PL}\end{array}$ & \pm 3.861 & 0.704 & $\begin{array}{l}\mathrm{S}=83.222+4.770 \mathrm{HL}-1.053 \mathrm{HB}-0.561 \mathrm{PL}+1.841 \mathrm{I}-0.964 \mathrm{M}+ \\
1.350 \mathrm{R}-1.137 \mathrm{P}\end{array}$ & \pm 3.786 & 0.724 \\
\hline $\begin{array}{l}\mathrm{S}=77.995-1.757 \mathrm{HL}+6.586 \mathrm{PL}+ \\
5.895 \mathrm{M}\end{array}$ & \pm 3.854 & 0.705 & $\begin{array}{l}\mathrm{S}=83.706+4.989 \mathrm{HL}-1.093 \mathrm{HB}-0.640 \mathrm{PL}+1.872 \mathrm{I}-1.064 \mathrm{M}+ \\
1.407 \mathrm{R}-1.102 \mathrm{P}-0.569 \mathrm{~T}\end{array}$ & \pm 3.794 & 0.725 \\
\hline $\mathrm{S}=77.049+4.836 \mathrm{HL}-0.607 \mathrm{HB}$ & \pm 3.761 & 0.720 & $\mathrm{~S}=83.386+4.881 \mathrm{HL}-0.954 \mathrm{HB}$ & \pm 3.827 & 0.696 \\
\hline $\begin{array}{l}\mathrm{S}=76.779+4.518 \mathrm{HL}-0.619 \mathrm{HB}+ \\
0.592 \mathrm{PL}\end{array}$ & \pm 3.769 & 0.720 & $\mathrm{~S}=83.490+4.621 \mathrm{HL}-1.096 \mathrm{HB}-0.096 \mathrm{PL}+0.953 \mathrm{I}$ & \pm 3.836 & 0.698 \\
\hline $\begin{array}{l}\mathrm{S}=74.626+7.394 \mathrm{HL}-2.400 \mathrm{PL}- \\
4.210 \mathrm{M}+1.269 \mathrm{R}\end{array}$ & \pm 3.773 & 0.721 & $\begin{array}{l}\mathrm{S}=83.734+4.895 \mathrm{HL}-1.085 \mathrm{HB}-0.378 \mathrm{PL}+0.820 \mathrm{I}+1.362 \mathrm{M}- \\
1.659 \mathrm{R}\end{array}$ & \pm 3.830 & 0.703 \\
\hline
\end{tabular}

Table 7: Multiple regression equations for hand and handprint measurements (in $\mathrm{cm}$ ) in unknown gender.

\begin{tabular}{|c|c|c|c|c|c|}
\hline \multicolumn{3}{|l|}{ Hand } & \multicolumn{3}{|l|}{ Handprint } \\
\hline Equation & SEE & $\mathrm{r}$ & Equation & SEE & $\mathrm{r}$ \\
\hline \multicolumn{6}{|l|}{ Right } \\
\hline $\mathrm{S}=51.254+4.394 \mathrm{HL}+2.315 \mathrm{HB}+1.361 \mathrm{PL}$ & \pm 4.609 & 0.837 & $\mathrm{~S}=50.022+7.191 \mathrm{HPL}+0.818 \mathrm{HPB}-1.679 \mathrm{PPL}$ & \pm 4.684 & 0.833 \\
\hline $\begin{array}{l}\mathrm{S}=52.826+4.027 \mathrm{HL}+2.004 \mathrm{HB}+1.389 \mathrm{PL}- \\
0.081 \mathrm{I}-1.016 \mathrm{M}+1.445 \mathrm{R}+0.896 \mathrm{~T}\end{array}$ & \pm 4.615 & 0.839 & $\begin{array}{l}\mathrm{S}=49.912+6.556 \mathrm{HPL}+0.697 \mathrm{HPB}-1.443 \mathrm{PPL}+ \\
0.667 \mathrm{IP}-0.592 \mathrm{MP}+1.110 \mathrm{RP}-1.077 \mathrm{PP}+1.340 \mathrm{TP}\end{array}$ & \pm 4.673 & 0.836 \\
\hline \multicolumn{6}{|l|}{ Left } \\
\hline $\begin{array}{l}S=51.759+15.076 \mathrm{HL}+1.610 \mathrm{HB}-9.523 \mathrm{PL}- \\
0.751 \mathrm{I}-12.301 \mathrm{M}+3.167 \mathrm{R}\end{array}$ & \pm 4.530 & 0.845 & $\begin{array}{l}\mathrm{S}=51.395+6.964 \mathrm{HPL}-0.034 \mathrm{HPB}-1.527 \mathrm{PPL}-0.527 \mathrm{IP} \\
+0.766 \mathrm{MP}+0.825 \mathrm{RP}\end{array}$ & \pm 4.728 & 0.828 \\
\hline $\begin{array}{l}\mathrm{S}=51.782+15.073 \mathrm{HL}+1.610 \mathrm{HB}-9.521 \mathrm{PL}- \\
0.764 \mathrm{I}-12.022 \mathrm{M}+3.140 \mathrm{R}+0.041 \mathrm{P}\end{array}$ & \pm 4.536 & 0.845 & $\begin{array}{l}\mathrm{S}=51.296+7.094 \mathrm{HPL}+0.008 \mathrm{HPB}-1.666 \mathrm{PPL}- \\
0.258 \mathrm{IP}+0.872 \mathrm{MP}+1.106 \mathrm{RP}-1.023 \mathrm{PP}\end{array}$ & \pm 4.722 & 0.829 \\
\hline $\begin{array}{l}\mathrm{S}=52.247+15.272 \mathrm{HL}+1.445 \mathrm{HB}-9.921 \mathrm{PL}- \\
1.115 \mathrm{I}-12.061 \mathrm{M}+2.944 \mathrm{R}-0.070 \mathrm{P}+0.926 \mathrm{~T}\end{array}$ & \pm 4.533 & 0.846 & $\begin{array}{l}\mathrm{S}=50.645+6.500 \mathrm{HPL}+0.093 \mathrm{HPB}-1.349 \mathrm{PPL}- \\
0.438 \mathrm{IP}+1.014 \mathrm{MP}+1.028 \mathrm{RP}-1.252 \mathrm{PP}+1.604 \mathrm{TP}\end{array}$ & \pm 4.699 & 0.831 \\
\hline
\end{tabular}

\section{Conclusion}

In conclusion, the hand length can be considered as the most needed criteria in stature estimation of a person. This is because the strongest correlations were found between stature and hand lengths for both gender and unknown gender. Besides, for stature estimation, the use of other hand dimensions such as palm length, hand breadth and fingers length will enhance prediction accuracy. The equations derived in this study would be helpful in order to obtain estimated stature of an individual when there is problem in obtaining direct measurement such as a dismembered body.

\section{Acknowledgement}

The authors are thankful to all the participants who had been volunteers and give good cooperation during the data collection. We are also grateful to anonymous reviewers who had revised this manuscript and appraised this topic of research.

\section{References}

[1] Hemy, N., Flavel, A., Ishak, N.I., Franklin, D. (2013). Estimation of stature using anthropometry of feet and footprints in a Western Australian population. Journal of Forensic and Legal Medicine, 20, 435-441.

[2] Kanchan, T., Krishan, K., Geriani, D., Khan, I.S. (2013). Estimation of stature from the width of static footprints-Insight into an Indian model. The Foot, 23, 136-139.

[3] Reel, S., Rouse, S., Vernon, W., Doherty, P. (2012). Estimation of stature from static and dynamic footprints. Forensic Science International, 219, 283e1-283e5.

[4] Moorthy, T.N., Mostapa, A.M., Boominathan, R., Raman, N. (2014). Stature estimation from footprint measurements in Indian Tamils by regression analysis. Egyptian Journal of Forensic Sciences, 4, 7-16.

[5] Agnihotri, A.K., Agnihotri, S., Jeebun, N., Googoolye, K. (2008) Prediction of stature using hand dimensions. Journal of Forensic and Legal Medicine, 15, 479-482.

[6] Ishak, N.I., Hemy, N., Franklin, D. (2012). Estimation of stature from hand and handprint dimensions in a Western Australian population. Forensic Science International, 216, 199e1-199.e7.

[7] Rastogi, P., Nagesh, K.R., Yoganarasimha, K. (2008). Estimation of stature from hand dimensions of north and south Indians. Legal Medicine, 10, 185-189. 
[8] Jee, S.C., Yun, M.W. (2015). Estimation of stature from diversified hand anthropometric dimensions from Korean population. Journal of Forensic and Legal Medicine, 35, 9-14.

[9] Paulis, M.G. (2015). Estimation of stature from handprint dimensions in Egyptian population. Journal of Forensic and Legal Medicine, 34, 55-61.

[10] Krishan, K., Sharma, A. (2007). Estimation of stature from dimensions of hands and feet in a North Indian population. Journal of Forensic Science and Legal Medicine, 14, 327-332.

[11] Uhrova, P., Benus, R., Masnicova, S., Obertova, Z., Kramarova, D., Kyselicova, K., Dornhoferova, M., Bodorikova, S., Nescakova, E. (2015). Estimation of stature using hand and foot dimensions in Slovak adults. Legal Medicine, 17, 92-97.

[12] Nor, F.M., Abdullah, N., Mustapa, A.M., Faisal, N.A., Nazari, D.A.A.A. (2013). Estimation of stature by using lower limb dimensions in the Malaysian population. Journal of Forensic and Legal Medicine, 20, 947-952.

[13] Khairulmazidah, M., Nadiah, N.A.B., Rumiza, A.R. (2013). Stature estimation using foot and shoeprint length of Malaysian population. International Journal of Medical, Pharmaceutical Science and Engineering, 7(7), 119-122.

[14] Krishan, K., Kanchan, T., Sharma, A. (2012). Multiplication factor versus regression analysis in stature estimation from hand and foot dimensions. Journal of Forensic and Legal Medicine, 19, 211-214.

[15] Moorthy, T.N., Zulkifly, N.R. (2014). Regression analysis for stature determination from hand anthropometry of Malaysian Malays for forensic investigation. Sri Lanka Journal of Forensic Medicine, Science \& Law, 5(2), 8-15.

[16] Sen, J., Kanchan, T., Mondal, N., Krishan, K. (2014). Estimation of stature from lengths of index and ring fingers in a North-eastern Indian population. Journal of Forensic and Legal Medicine, 22, 10-15. 